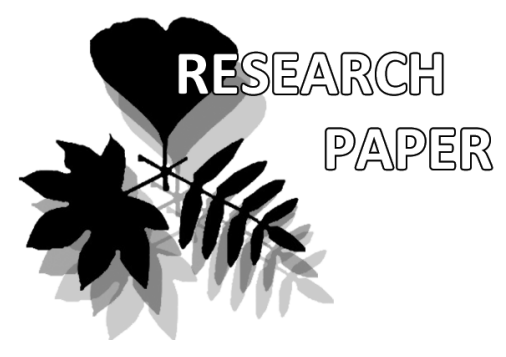

\title{
Anther morphology and pollen development in Trollius ledebourii Rchb. (Ranunculaceae)
}

\author{
Liubov V. Buglova* \& Olga Y. Vasiljeva
}

Liubov V. Buglova *

mail: astro11@rambler.ru

Olga Y. Vasiljeva

mail: vasil.flowers@rambler.ru

Central Siberian Botanical Garden SB RAS, Novosibirsk, Russia

* corresponding author

Manuscript received: 17.08.2017

Review completed: 12.11.2017

Accepted for publication: 21.11.2017

Published online: 23.11.2017

\begin{abstract}
A B S T R A C T
The paper focuses on anther structure, pollen mother cells meiosis, tapetum, post-meiotic pollen development and development abnormalities of all its structures in Trollius ledebourii Rchb. (Ranunculaceae). Microsporangium layers were established to develop centripetally; meiosis is synchronous within one locules, but considerably prolonged within one flower. Cell walls developed simultaneously. Type and frequency of abnormalities were determined to depend on stamen location in receptacle spiral. Abnormalities of meiotic spindle functioning as forming tetrads with various chromosome set or even apoptosis were registered only in the first anther row. They may result in $100 \%$ pollen sterility. Fertility and vitality of rape pollen were estimated. The procedure of pollen loss evaluation has been proposed. We pioneered to reveal in Ranunculaceae irregular shift of some part of archesporial cells to sterile development with appearing tapetal-like cells, but larger and shorter-living. They are defined as trabeculas and may serve additional nutrition for meiocytes.
\end{abstract}

K e y w o r d s : Trollius ledebourii, Ledebour globeflower, anther, pollen, microspore mother cell, tapetum, microsporangium wall

\section{P E 3 Ю M E}

Буглова А.В., Васильева О.Ю. Структура пыльника и развитие пыльцы у Trollius ledebourii Rchb. (Ranunculaceae). В статье описаны структуры пыльников и тапетума, мейоз материнских клеток пыльцы, постмейотическое развитие пыльцы и ее аномалии у Trollius ledebourii Rchb. (Ranunculaceae). Кıеточные слои развиваются центростремительно; мейоз синхронен в пределах микроспорангия, но значительно растянут в пределах одного цветка. Развитие клеточной стенки симультанное. Было установлено, что тип и частота анома^ий зависят от положения тычинок на спирали цветоложа. Аномалии функционирования веретена деления, приводящие к формированию тетраА с различным набором хромосом, а так же апоптоз регистрировались только в первом ряду пыльников. Эти явления могут привести к 100 \% стерильности пыльцы. Выполнен учет фертильности и жизнеспособности пыльцы, предложена процедура оценки потерь пыльцы. Мы впервые обнаружили в семействе Ranunculaceae сдвиг некоторой части археспориальных клеток к стерильному развитию с образованием клеток похожих на тапетум, но более крупных и с меньшим периодом существования. Они идентифицированы как трабекулы и могут служить АОполнительным питанием Аля мейоцитов.

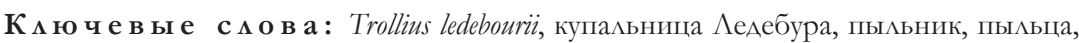
археспориальная кАетка, тапетум, стенка микроспорангия
Trollius ledebourii Rchb of section Longipetala, a representative of Ranunculaceae family, in wild occurs in wet meadows from the western part of its area in East Siberia spreading further east to Japan (Doroszewska 1974, Kadota 1987, Luferov 1995, Malyshev 2012). Ledebour globeflower and especially its subspecies having numerous (up to 12) yellowish-orange sepals is a deserving medicinal and adornment plant for growing in cold humid or temperate climate. Valuable traits of the species are its strong winter-hardiness and disease-resistance. In its nearest relative $T$. chinensis there were discovered flavonoids possessing proved cancerfighting properties (Wang et al. 2016). Bio-active substances of T. ledebourii are being thoroughly studied as well (Zou et al. 2004, 2005, Wu et al. 2011). As in wild the species oc- curs in hard-to-reach regions of Siberia and Mongolia, its introduction and mass reproduction turn urgent, thus allowing further research on its useful properties. T. ledebourii is a tall plant up to $1 \mathrm{~m}$ with big yellowish-orange flowers up to $6 \mathrm{~cm}$ in diameter (Li \& Tamura 2001, Friesen 2003). An androecium is represented by numerous free stamens with quadrilocular anthers. Collecting material for study is very difficult as plants grow in almost inaccessible regions of Siberia and the Far East. So there are few literature data on the species, while results on Central and East Siberia completely lack.

The peculiarity of $T$. ledebourii is later flowering time (mid June - early August) compared to other species of Longipetala section, which grow in western regions of Asia 
(Buglova 2011a). Absence of the physiological type of dormancy and rather fast germination of seeds, with the embryo developed to elongated cotyledons are typical characteristics of T. ledebourii being uncommon within the genus (Buglova et al. 2011).

Introduction of any useful plants to the regions with cold continental climate demands studying their ability to survive in environmental conditions, which are new to them. Reproductive ability and adaptive reactions development are of the main importance.

The male generative part of the species is not studied, though it is the most vulnerable. There are only some general data on Trollius genus in literature such as simultaneous cytokinesis, tetrahedral location of microspores, two-celled pollen grains (Sokolovskaya 1981, Kamelina 2009). Microsporangium wall, protecting and supplying the growing pollen, usually consists of epidermis, endothecium of the middle layer and tapetum. Tapetum is a cell layer directly adjacent to sporogenous tissue which affects the microsporocyte production. Abnormalities in tapetum development induce degeneration of tetrads and pollen (Bhandari 1984.). Not only the whole complex of biotic and abiotic factors influences the pollen formation, but even the flower position on the inflorescence and location of a stamen inside the flower (Ter-Avanesyan 1957). All of that is especially expressed in species forming abundant stamens.

Besides, microsporangium and the whole anther structure play a great role for specifying issues regarding to physiology, plant taxonomy and evolutionism (Bhandari 1971, Batygina 1994).

The only work within Trollius genus including modern methods of cytoembryological analysis has been performed in Megaleranthis saniculifolia Ohwi, or Trollius chosenensis Ohwi (Jang \& Heo 2005). As the authors aimed to confirm the taxonomic treatment of the species under the study, we also set off and compared the analogous group of features. Our investigation is supposed to contribute to creating a bank of cytoembryological characteristics of Trollius species.

\section{MATERIAL AND METHODS}

T. ledebourii plants were grown in the collection of the Central Siberian Botanical Garden SB RAS, Novosibirsk (CSBG). The study was conducted in 2012-2015. The initial material was collected in Transbaikalia (Zabaikal'skii Region) and brought as living plants. Samples were identified in LE (St.-Petersburg, Russia) herbarium as Trollius ledebourii Reichib. var. polysepalus Regel et Til. They differ from the type specimen (LE) in larger number of sepals (up to 12). However, modern systematics does not classify T. ledebourii into subspecies so we don't use the name of the subspecies furthermore (Li \& Tamura 2001, Malyshev 2012). For the study young generative (g1) and middle-aged generative (g2) individuals were used.

All the objects were diploids with karyotype $2 \mathrm{n}=16$ corresponding to natural characteristics, and no chromosome abnormalities were distinguished by microscopy (Doroszewska 1967, Sha et al. 1995, Buglova \& Krasnikov 2015).

To define the position of stamens, the outer row adjacent to petals was considered to be the first one, reading the following rows inside from it. The last row was the inner one near the carpels.

To determinate pollen vitality, it was collected to paper bags at 10-11 a.m. in dry and sunny weather conditions, at $20-25^{\circ} \mathrm{C}$. The pollen was densely inoculated onto a mount to a drop of nutritional medium with $1 \%$ agar and $9 \%$ sucrose. Then slides with pollen were placed on moisture filter paper in Petri dishes. The temperature of germination was $22-24^{\circ} \mathrm{C}$. Number of germinated grains was first counted in 24 hours after inoculation.

To study the sporogenous tissue and microsporangium wall genesis, pollen grains were FAA (70\% ethanol - $90 \mathrm{ml}$, glacial acetic acid $-5 \mathrm{ml}, 38 \%$ formaldehyde $-5 \mathrm{ml}$ ) fixed and classical permanent slides were stained with Heidenhain's hematoxylin - alcian blue (Prosina 1960). The last stages of pollen development were studied on squash preparations stained with propion acid.

Fertility was estimated by biochemical analyzing of FAA-fixed or aero-dry pollen. Starch content was evaluated by iodine test of pollen grains (using the IKI solution iodine dissolved in aqueous solution of potassium iodide). 2066 pollen grains were examined for general analysis of fertility, and 500 ones - to assess their death at early stages of gametogenesis.

To treat the data obtained and to perform statistical analysis Student's t-distribution was applied.

Big objects were viewed with a SteREO Discovery V12 stereomicroscope, for microscopy Axioscop-40 was used, photos taken by AxioCam MRc-5 camera, while for processing images the program AxioVision 4.8 was applied in the common use center of CSBG.

\section{RES U LT S}

\section{General description}

In $T$. ledebourii numerous stamens are arranged in several rows around the carpel on a convex receptacle, the same as for all the representatives of the genus. Pollen ripening is considerably prolonged, so pollen emergence was observed to last for about 7 days under normal weather conditions $\left(18-25^{\circ} \mathrm{C}\right)$, and about 5 days when it was hot (more than $30^{\circ} \mathrm{C}$ ).

A ripe anther of T. ledebourii is about $4.5 \mathrm{~mm}$ long, bilaterally symmetrical (Fig. 1). It consists of 4 microsporangia arranged in pairs and a wide connective. Microsporangia pairs are separated by a thin septum (Fig. 2a). A young microsporangium wall was revealed to consist of 5(6) layers: epidermis; endothecium; 2-3 middle layers; secretory tapetum. 4-5 parenchyma layers comprised the septum between the neighboring thecas. Its cells were slightly flattered and radially extended at the meiotic period. In post-meiosis they increased in size, vacuolated and their shape was close to isodiametric. In a mature microsporangium the septum was kept and a stomium was formed at the juncture of its attachment to the microsporangium wall. Dehiscence of microsporangia occurred by longitudinal slits upwards from the bottom.

Connective cells were represented by large loose parenchyma with a conducting bundle in the center. It was covered from outside with epidermis and there were no specific tissues in adjacent to the anthers area. Parenchymal cells 


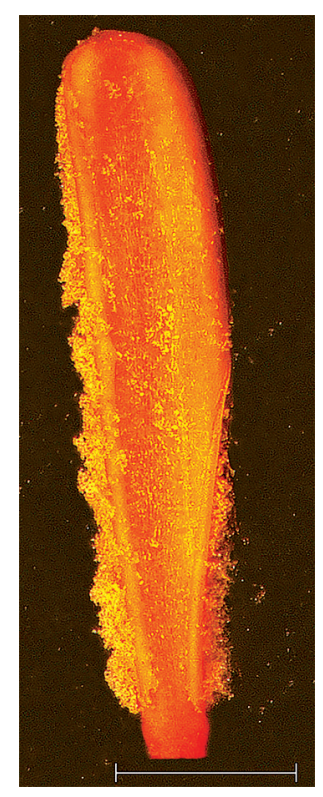

Figure 1 Anther, general view in pollen emergence period. Scale bar: $1 \mathrm{~mm}$

of the connective were large, highly vacuolated and slightly elongated along the anther axis.

\section{Normal microspore mother cells (MiMC) meiosis}

In T. ledebourii sporogenous tissue had 4-6 layers. Prior to meiosis, MiMC were round or oval with dense cytoplasm and had large nuclei with single nucleolus, size of MiMCs was about 9-12 $\mu \mathrm{m}$. By the end of diakinesis the nucleolus disappeared. Rapid metaphase I could rarely be registered. Complete chromosome de-condensation did not occur during telophase I; interkinesis was short (up to its total absence). Spindle axes were normally arranged parallel. At the end of anaphase II a short-living predecessor of a cell septum was observed. The resultant microspore tetrads were tetrahedral and the general callosal coat was thin at all stages. Phragmoplast formation went centripetally and synchronous, cytokinesis was simultaneous. Meiosis happened rather rapidly and synchronously within one pollen sac. However, ripening of stamens within one flower was considerably prolonged. As a rule, the microspore stage was observed in the first anthers situated near petals, though meiosis only began in the last ones (near the style). Insignificant asynchrony in stages of development was possible to detect even among microsporangia of the same anther (Fig. 2c).

\section{Pollen development}

Post-meiotic period was more prolonged than the meiotic one. It might be divided into several stages: microspores, vacuolated uni-nucleate pollen, mitosis, post-mitotic period, pollen grain (PG) formation, mature pollen grain.

Microspore stage began with mutual tetrads repulsion inside their common coat. By its dissolution microspores lay singly, nuclei were big and basophilia was lowered. Amoeboid shape of cytoplasm and intensive enlarging of microspores can be highlighted as characteristic features of this stage, the ratio of nucleus and cytoplasm volumes significantly changing in favour of cytoplasm.

During the stage of vacuolated uni-nucleate pollen, growth along the line of developing colpi ceased, being in progress in other directions, so the cells shape turned trilobate from the pole and their walls thickened (Fig. 2d).

The PGs entered asymmetric mitosis being trilobate, but to the end of this stage they got rounded again (Fig. 2d, 2f). Mitosis ran rather fast, but for its long telophase; nuclei occupied the center of the grain.

In the course of the following stages PG size increased slightly and pollen wall sculpture formation took place. The inner content of the grain could be scanned poorly. Game- tophyte contained two nuclei of different shape and size: an oval generative nucleus and a formless vegetative one (Fig. 2f). Due to dehydration PGs obtained oval trilobate shape once again. Basophylia increased dramatically, though it decreased by the complete ripening. Size of formed twocelled moist PGs was 17.26 $\pm 0.71 \mu \mathrm{m}$ and of mature pollen $-18.85 \pm 0.23 \mu \mathrm{m}$ (Table 1$)$. The nucleus of a vegetative cell was oval. A generative cell was lens-shaped and large.

Trilobate shape and absence of vacuolating stage in vacuolated uni-nucleate pollen should be considered as peculiar characteristics of post-meiotic period in T. ledebourii.

\section{Meiotic abnormalities}

We had revealed the correlation between types of abnormality during meiosis and stamens arrangement on the receptacle. In the last (inner) and middle rows of stamens there were registered incidental rare chromosome ejections beyond the metaphase plate or delay of individual chromatids. Pollen formed appeared to look normal.

In the first row both phenomena occurred, including non-disjunction with chaotic dislocation of conglutinated chromosome groups to the cell wall (Fig. 3a). Chromosome ejections in some cases were so intense that typical metaphase was not seen. As a result, faulty tetrads were formed.

Death of microspore tetrads with cell volume diminution was recorded either, which is specific for apoptosis (Fig. 3b). Apoptosis was recognized by typical indicators of pathological pycnosis of nuclei and basophylia increase in cells (Kerr 1971). On the contrary, normal microspore tetrads are round-shaped (Fig. 2b).

Besides, abnormalities of meiotic spindle functioning were registered. Those were revealed at stage of tetrads, as the process of meiosis resulted in products which varied in size and chromosome structure. Among them there were observed abnormal dyads with 2 nuclei in a cell or with incomplete division if nuclei; triads and tetrads with zero chromosomes number in one cell and undivided nuclei in another one. Undivided nuclei had a specific shape with a contractive ring. Within a pollen sac that caused up to $100 \%$ defectiveness of PGs and their degeneration.

The only phenomenon independent from stamen location was meiosis break off during interkinesis stage with restitutive nuclei forming. This accidentally happened amongst meiocytes which divided properly.

\section{Anther wall development}

Young anther was observed to develop 5 layers, whereas there were only 3 of them left in a mature one: fibrillose epidermis; fibrous endothecium; middle layer. Differentiation of microsporangium layers was not clearly defined as centripetal, because the process of differentiation of all cells took place almost concurrently with just a little earlier isolation of two first layers of an anther.

Epidermis developed during pre-meiosis and meiosis. By the end of meiosis this layer was represented by large highly vacuolated and axially elongated cells with little nuclei. The outer (tangential) cell wall was even without any peculiarities; cuticle and radial septum were thin. During post-meiosis epidermis cells underwent partial dehydration. 


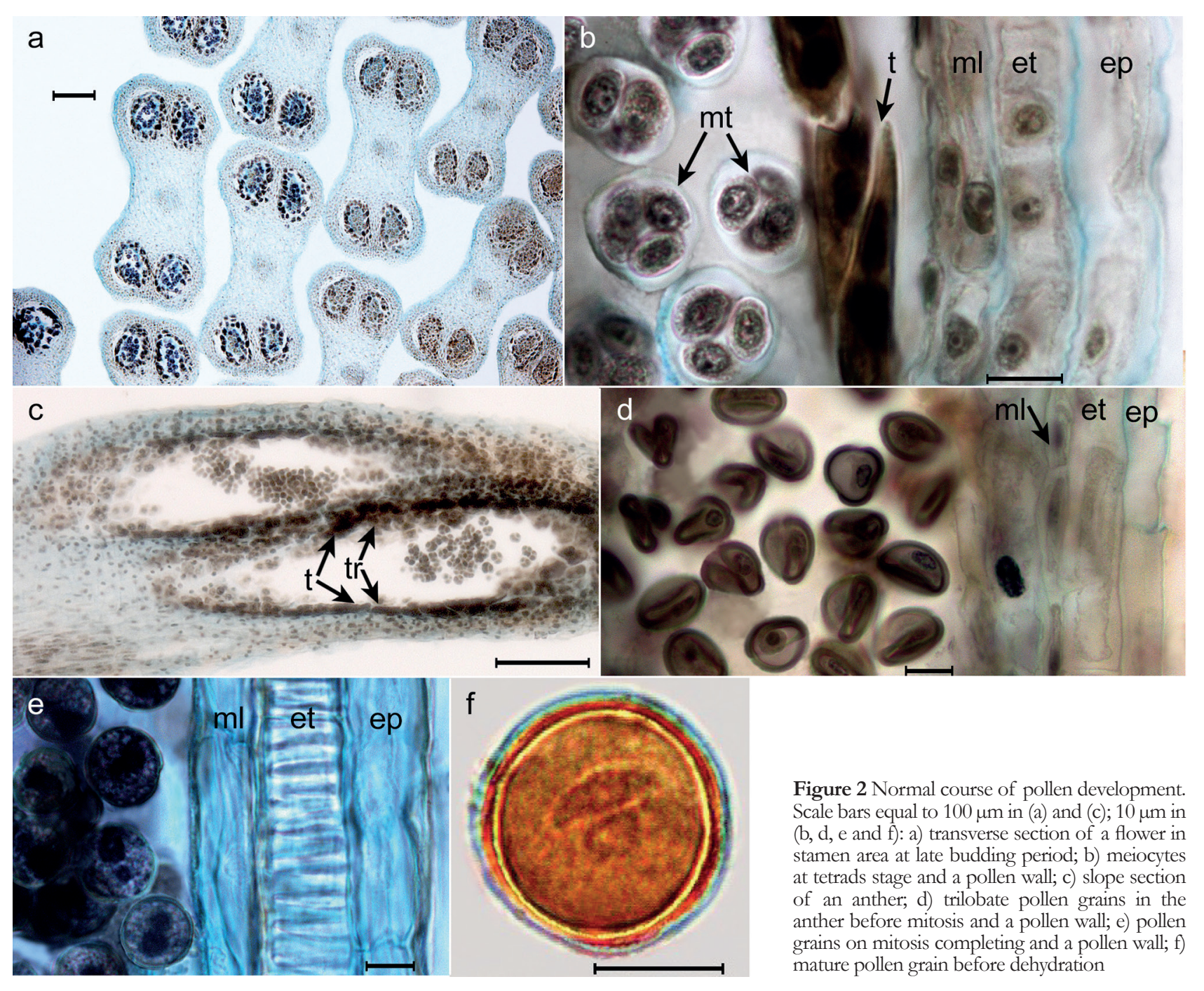

Differentiation of endothecium began at pre-meiotic period. Its cells vacuolated and became bigger than the cells of epidermis. At post-meiotic period fibrous thickenings started forming during mitosis in PGs. They stopped radial growth; therefore, axial growth was still in progress. Endothecium was the thickest layer of a ripe microsporangium; cells were highly vacuolated, with little and hardly stainable nuclei. Narrow fibrous thickenings reached the opposite wall of the cell and formed a ladder-like structure (Fig. 2e).

Middle layer normally consisted of 2 rows. Cells of the first row being adjacent to endothecium did not develop and stayed crushed throughout all the meiotic period and slightly enlarged in post-meiosis (Tabl. 1). Cells of the second middle row almost didn't get larger. During meiosis they shrank radially and crushed. Their degeneration coincided with mitosis in PGs. In some individual plants there could be identified the additional third diffusive and barely distinguishable layer of cells which were arranged loosely. They didn't enlarge and soon shrank and underwent lysis. Usually this layer degenerated at early meiosis, but in rare cases it could be detected up to the end of meiotic period. Time of its existence varied even within different anthers of the same plant.

During preparing to pollen emergence, lysis occurred in middle layer and septum. There were no fibrous thickenings in the stomium cell connecting two neighboring pollen sacs, so tension grew in endothecium due to intensification of dehydration, thus leading to dehiscence of the anther.

Process of forming microsporangium wall layers scarcely correlated with types of microsporocytes formation abnormalities and defective PGs production. Despite meiosis disruptions and mass death of microspore tetrads being registered, differentiation of all the covering layers and normal vacuolization of wall cells took place. Otherwise, fibrous thickenings formation in endothecium of anthers with $100 \%$ faulty pollen was considerably reduced (up to complete absence), period of middle layers existence elongated either.

\section{Tapetum genesis}

Unlike other layers of anther wall, tapetal cells surround the sporogenous tissue on all sides. Tapetum differentiation was revealed to start at pre-meiotic period. In the course of normal development, in early meiosis tapetum was observed to comprise slightly vacuolated cells adjacent to microsporocytes and having large nuclei which occupied up to half of cytoplasm. Later, a cavity filled with locular liquid appeared between tapetum and a microsporangium wall. After meiosis was completed, microspores drastically enlarged and pressed the tapetal cells aside to the microspo- 
rangium wall. T. ledebourii has secretory (glandural) tapetum with large two-nucleate cells of various shapes. At the top and bottom ends of the anther isodiametric cells were observed. In lateral areas of microsporangium they took a strongly elongated shape and formed a single loosy layer. In all the tapetal cells chromosomes during meiosis were partly spiralized. Most cells underwent one mitotic division and there appeared two-nucleate and seldom tri- or tetra-nucleate cells. Fragmoplast might not be formed, or was formed centripetally. Mature tapetum normally consisted of twonucleate cells. In T. ledebourii plants under the study this layer had rather long functional lifetime (Table 1). Tapetum should be considered as mature at the stage of microspore tetrads when its basophylia was most expressed (Fig. 2b). Then basophylia level decreased and cells enlarged, those were preparing to lysis. Lysis of tapetum was prolonged, it lasted during the whole period of vacuolated uni-nucleate PG envelop forming and finished by the beginning of mitosis (Fig. 2d).

Mechanism that caused errors in the normal course of meiosis in sporogenous tissue correlated with tapetum genesis abnormalities. Mitotic disruptions were typical for anthers with wrong meiosis in meiocytes. In tapetal cells we had observed intensified chromosome condensation, nondisjunction with forming bridges or restitutional nuclei. Higher intensity of mitosis and shifting of its genesis phases towards longer time of existence were fixed in tapetum of the outer anthers, where abnormal pollen percentage was very high (up to $100 \%$ ). Therefore, mature tapetum basophylia in this case was lowered in comparison to normal tapetum.

\section{Additional microsporangium sterile cells}

We had first revealed for Ranunculaceae additional sterile microsporangium structures presence in T. ledebourii. As those structures appeared to differentiate from archesporium cells earlier than MiMC and tapetum, we considered them to be trabeculas. Genesis occurred during meiosis. Trabeculas were usually two-nucleate due to mitosis without phragmoplast forming, or rarely tetra-nucleate. Chromosomes in large nuclei were partially condensed. Trabeculas were 2-4 times larger than meiocytes, tapetum-like; their lifetime was considerably shorter than of tapetum, while basophylia level was lower. In early meiosis they enlarged

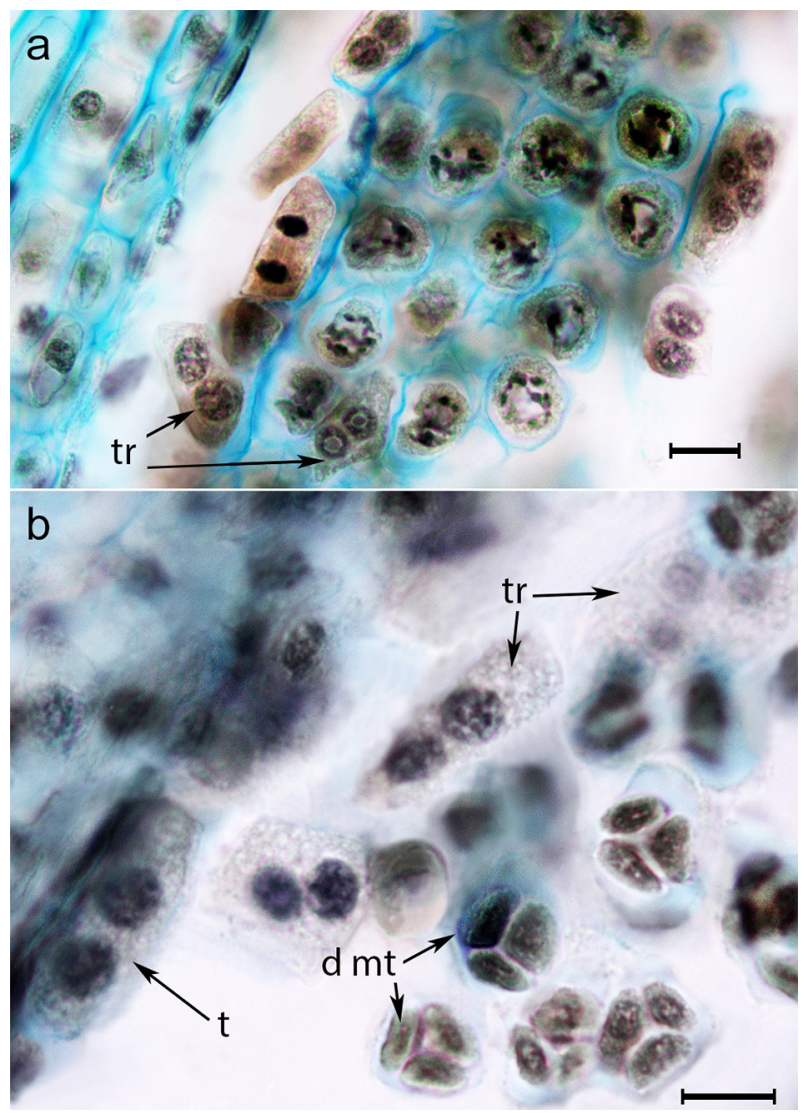

Figure 3 Meiosis abnormalities; $\mathrm{d}$ mt-microspore tetrads; ep - anther epidermis; et - endothecium; $\mathrm{ml}$ - middle layer; $\mathrm{mt}$ - microspore tetrads; $\mathrm{t}$ - tapetum; tr - trabecula; a) meiotic period; b) tetrad stage

sharply (Fig. 3). Trabeculas degenerated at the tetrads stage and this process was completed during the microspore stage. They did not form a permanent layer but occurred as 2-4 layers in microsporangiums with normal pollen development at the ends of anthers, where they could replace the tapetum. More rarely trabeculas were situated in 1-2 layers in the lateral area between tapetum and microsporocytes. In the central part of the theca then a minor amount of visually normal pollen was formed (Fig. 3b). Trabeculas appearing in the central part of the anther locules, or their forming more than 2 layers in lateral areas always indicated that all the surrounding meiocytes would get abnormalities through meiosis forming faulty tetrads.

Table 2. Sporogenous tissue and anther wall cells size in different stages

\begin{tabular}{|c|c|c|c|c|c|c|}
\hline \multirow[t]{2}{*}{ Stage } & \multicolumn{5}{|c|}{ Layers of microsporangium wall, $\mu \mathrm{m}$} & \multirow{2}{*}{$\begin{array}{c}\text { Meiocyte/ } \\
\text { Gameto-phyte, } \\
\mu \mathrm{m}\end{array}$} \\
\hline & epidermis & endothecium & middle layer(1) & middle layer(2) & tapetum & \\
\hline \multicolumn{7}{|l|}{ Sporogenesis } \\
\hline Early meiosis & $9-10$ & $9-11$ & $3-4$ & $3-4$ & & $9-12$ \\
\hline Meiosis (telopase II) & $10-12$ & $11-13$ & $5-5.5$ & $3-5$ & $\leq 10.5$ & 9-12 \\
\hline Microspore tetrads & $12-15$ & $11-12$ & $7-8$ & $2-4$ & $9-12$ & $10.5-12$ \\
\hline \multicolumn{7}{|l|}{ Gametogenesis } \\
\hline Microspore & $12-15$ & $11-12$ & $7-8$ & $2-4$ & $9-12$ & $5-9$ \\
\hline Uni-nucleate pollen & $7-15$ & $12-17$ & $7-8$ & $2-4$ & $6-9$ & $12-13$ \\
\hline Colpi formation & $14-15$ & $15-18$ & $13-15$ & crushed & lysis & $13-15$ \\
\hline Mitosis, end & $12-14$ & $17-19$ & $\leq 7$ & lysis & - & 15 \\
\hline Formed PG & $14-16$ & $18-19$ & $10-13$ & - & - & $16-18$ \\
\hline Ripe PG & $14-16$ & $19-20$ & $10-13$ & - & - & $18-19$ \\
\hline
\end{tabular}




\section{Pollen quality and losses estimation in the post-meiotic period}

The most difficult task was to estimate PG loss in postmeiosis. Eventual elimination of faulty products of meiosis took place at the spore stage. Afterwards the developing PGs formed thick envelopes which were not subject to lysis. As a consequence, not any further abnormalities could be detected by microscopy. Thus, usually only PG quality was analyzed by evaluating fertility and vitality of rape pollen.

Pollen vitality was determined by germination on nutrient medium. First, best conditions and nutrient media were selected. For T. ledebourii PGs growing 7-9 \% sucrose and $1 \%$ agar media without any additives were the most preferable. Optimal temperature for Trollius pollen was $21-24^{\circ} \mathrm{C}$, its rising up to $25^{\circ} \mathrm{C}$ or more led to germination efficiency reduction, as growth rate of pollen tubes lowered dramatically. Pollen vitality was also found to depend on the air humidity, as pollen collected in moist weather showed lower percentage of germinated PGs and a quick loss of germination ability. Under optimal condition on $9 \%$ sucrose medium, germination of $60-75 \%$ of PGs was registered, being quite a good result. There were formed functional pollen tubes, sized several times more than PGs' diameter.

Fertility estimation by IKI treatment revealed $32.7 \%$ PG with $0-25 \%$ of staining expression and $67.3 \%$ PG with 50-100\%. PGs with 25-50\% of staining were not taken into consideration at all. Data on fertility appeared to be amazingly similar to the ones on vitality. Such coincidence is unnatural, as vitality is usually lower compared to fertility.

However, the obtained results made it possible to assume the death of PGs in early stages of development, before they reached their full size and stored enough nutrients for germination. To adjust the presumption we performed indirect estimation of correlative interaction between PG sizes and their staining for starch content. Standard direct technique could not be applied, revealing only minor natural correlation not conforming to our hypothesis. For the purpose we chose random group № 1, their diameter being measured (Table 1). From this group of PGs the group № 2 with starch content of $25-100 \%$ was selected by IKI staining. Theoretically, for such groups data on PG diameter should not differ statistically.

Therefore, Student's t-distribution for the two groups turned to be 3.98, which meant groups under the study differed in $0.01 \%$, thus pointing to significant correlation of the two characteristics (PG size and starch content). We consider incredibly high level of correlative links by Student's t-test to result from pollen early death and consequent presence of numerous little (10-14 $\mu \mathrm{m})$ unstained PG walls. Such empty PG walls were not stained by nuclear dyes. They were lost during pollen germination on nutrient medium and its following registration, but were taken into account in biochemical staining. Consequently, the results on fertility and vitality of PGs were so unnaturally close. This rather simple method was likely to work well for registering PG death on uni-nucleate pollen stage, when PG walls were formed, but nutrients had not been stored yet (Table 2). In our further investigation we determined ripe pollen diameter in T. ledebourii only for the pollen being IKI stained not less than $50 \%$ to yield more correct results (Table 1).

\section{DISCUSSION}

\section{Comparative anther morphology}

Cytoembryology in T. ledebourii has not been studied by other authors before our works (Buglova 2011b, Buglova 2015, Buglova \& Krasnikov 2015, Buglova 2016). The only work on reproductive characters within Trollius genus including modern methods has been performed by Jang \& Heo (2005). Photos of microsporangium presented in their paper were taken in the same manner as in ours, making it possible to conduct comparison studies. Disputing taxonomy issues is beyond the scope of our study; nonetheless, we couldn't stay indifferent towards applying reproductive characters for taxonomy purpose by Jang \& Heo (2005).

Position of T. ledebourii in systematic is doubtless, while belonging Megaleranthis saniculifolia Ohwi to genus Trollius is still controversial (Kim \& Lee 1987, Lee 1990). That is why it was interesting to compare their anthers.

According to the work of the authors mentioned above and our study, common traits for both species are: tetrasporangiate anthers; secretory (glandural) tapetum, mainly twonucleate and showing heightened basophylia in late meiosis; fibrous endothecium; persistent epidermis. Simultaneous cytokinesis and tetrahedral arrangement of microspores are typical for meiosis. PGs are two-celled (Jang \& He 2005).

Unfortunately, a very laconic description of microsporangium is brought by the authors, however good quality photos from the paper make it possible to detect one distinction. That is the curved structure of the anther in Megaleranthis saniculifolia Ohwi, with the only transversal axis of symmetry. On the contrary, transverse section of an anther of T. ledebourii possesses 2 axes of symmetry (Fig. 2a).

\section{Partial pollen reduction as an adaptive phenomenon}

Our study has confirmed the primitive structure of anther in T. ledebourii, which is a typical representative of Ranunculaceae family. Bilateral symmetrical arrangement of microsporangiums and two-nucleate PGs with 3 colpi refer to primitive character traits. Peculiarities of PG development in Trollius are: slightly expressed and rather centripetal development of microsporangium wall layers; trilobate shape at pre-mitotic stage; absence of vacuolating stage in vacuolated uni-nucleate pollen; trabeculas forming.

It is worth noting that potential pollen productivity in T. ledebourii is high. Every flower produces about 80-100 stamens; anther consists of 4 pollen sacs, in each one there are 5(6) rows wide and 35-40 rows high of archesporial cells, which can potentially provide up to 4500 PGs per anther. There is no necessity for an entomophilous species in producing such an abundant amount of pollen. However, reduction of stamens does not take place. Instead, the species uses other ways to save on unneeded energy consumption.

There are initiated numerous archesporial cells. Pollen reduction occurs during both meiosis and gametophyte development. It is a natural process for the species, as apoptosis is a program of death. Prerequisites for stamens reduction are most clearly followed in anthers, which ripe first. For them, abnormalities of meiotic spindle forming were registered, which resulted in forming abnormal tetrads be- 
ing unable to further development. Similar phenomena of tetrads formation with unequal amount of nuclear substance were earlier described for male sterile plants (Shamina et al. 2004, 2006, Shamina \& Dorogova 2006).

Larger number of empty PG walls as compared to other species of globeflowers proves rather high level of PGs death in post-meiotic (gametophyte) stage of development.

Under conditions of continental climate, large number of stamens can provide adaptive benefits, as it makes possible to prolong pollen ripening period. It is an adaptive reaction of the species to sharp hydrothermal extremes. For some part of pollen conditions turn to be favourable for its development. Probably, that is why reduction of stamens number does not occur in Trollius, even though there is tendency of forming unviable pollen and high range of tetrads degeneration in the outer row. Thus, the species has got natural mechanisms of "intended" pollen loss such as: sterile stamens of first ripening; trabeculas forming from some part of archesporial cells; and just apoptosis of tetrads.

Development of additional sterile cells inside the microsporangium is a rare and poorly studied phenomenon in Magnoliophyta. Similar structures were described for Verbenaceae, Lamiaceae, Bignoniaceae as radial growth of cells of a connective adjusted to microsporangium inner sides and named for those families as placentoids (Feyberg 1987, Kamelina \& Dzevaltovsky 1987). In Gentianaceae trabeculas forming instead of tapetal cells was registered (Shamrov 1986, 1987, 1988). Peculiarity of trabecules in Trollius is their irregular development from archesporium, loosy arrangement and short life period. We assume them to be additional nutrition for meiocytes.

Initially, trabeculas development may probably have appeared as abnormality, which can be confirmed by their often occurrence in the first row of stamens. On the other hand, expansion to northern and alpine regions has demanded additional endo-nutrition of reproductive elements; and partial transformation of microsporangial inner cells to trabeculas may have been kept as an adaptive character. It should be noted, that trabeculas number varies greatly within both one flower and different individual plants. Trabeculas occurrence in other holarctic species of the genus needs further investigation.

As there are few works on cytoembryology in other species of Trollius, studies should be conducted to continue determination of taxonomic characters and to refine the phylogeny of the genus. Valuable medicinal properties discovered in T. ledebourii and T. chinensis make other species of the genus attractive for further study.

\section{CONCLUSIONS}

For $T$. ledebourii microsporangium layers have been found to develop centripetally; meiosis being synchronous within one pollen sac, but considerably prolonged within one flower. Cell walls develop simultaneously. Mature moisture fertile pollen is 2-celled rounded, tricolpate. Dehydrated pollen is oval, trilobate from the pole. Vegetative nucleus is oval and a generative cell - lens-shaped and large.

Only 3 of 5 layers of a young microsporangium are left in a mature one: fibrillose epidermis, fibrous endothecium and a middle layer which undergoes lysis immediately prior to the emergence. Tapetum is glandural, loosy, monolayered of 1-4-nucleate cells. Mature tapetal cells are normally twonucleate.

Type and frequency of abnormalities have been revealed to depend on stamen location in receptacle spiral. Abnormalities of meiotic spindle functioning as forming tetrads with various chromosome set or even apoptosis were registered only in the first anther row. They may result in $100 \%$ pollen sterility.

Pollen development cease was observed at early gametogenesis stages, leading to little starch-free empty PG walls formation.

The study pioneered to reveal in Trollius irregular shift of some part of archesporial cells to sterile development. Appeared cells have been defined as trabeculas and might serve additional nutrition for meiocytes. Along with high vitality level of mature pollen, this should prove high environmental phenotypic plasticity of the species. Thus, T. ledebourii can be strongly recommended for cultivation as both medicinal and adornment plant.

\section{ACKNOWLEDGEMENTS}

We are grateful to Ivan I. Shamrov for kindly consulting during the process of trabeculas determination and Tatiana V. Kolomyjchuk for help with translation.

\section{LITERAT URE CITED}

Batygina, T.B. (ed.) 1994. Embryology of Flowering Plants. Terminology and concepts. Generative organs of flower. Vol. 1. Mir i Sem'ya, St-Peterburg, 518 pp. (in Russian). [Эмбриология цветковых растений. Терминололгия и концепции. Генеративные органы цветка. / под ред. Т.Б. Батыгиной. С-Петербург: Мир и семья. Т. 1. 518 с.].

Bhandari, N.N. 1971. Embryology of the Magnoliales and comments on their relationships. Journal of the Arnold Arboretum 52(2):285-304.

Bhandari, N.N. 1984. The microsporangium. In: Embryology of angiosperms (B.M. Johry, ed.), pp. 53-121, University of Delhi, Delhi.

Buglova, L.V. 2011a. Rhythm of flowering of some Trollius L. species in Novosibirsk region. Vestnik Irkutskoi gosudarstvennoi sel'skohozyaistvennoi akademii 44(3):35-41 (in Russian). [Буглова А.В. 2011. Ритмы цветения некоторых вилов Trollius L. в условиях Новосибирска // Вестник ИрГСХА. Вып. 44, № 3. С. 35-41].

Buglova, L.V. 2011b. Histochemical study of ovules of two species of Trollius (Ranunculaceae). Rastitel'nyi mir Asiatskoi Rossii 2(8):100-103 (in Russian). [Буглова А.B. 2011. Гистохимическое исследование семязачатка Авух видов Trollius (Ranunculaceae) // Растительный мир азиатской России. № 2(8). C. 100-103].

Buglova, L.V., O.V. Kuznetsova \& Y.G. Nekrashevich 2011. Biological peculiarities of seeds in some special of Trollius L. and Paeonia L. Uchenye Zapiski Zabaikal'skogo gosudarstvennogo pedagogicheskogo universiteta. Seriya Estestvennye nauki 1(36):151-157 (in Russian). [Буглова А.В., Кузнецова О.В., Некрашевич Я.Г. Биомогические особенности семян некоторых вилов Trollius L. и Paeonia L. // Ученые записки ЗабГПУ, сер. Естественные науки. 2011. № 1(36). C. 151-157].

Buglova, L.V. 2015. The study pollen grain fertility, viability and its preservation period at the genus Trollius 
(Ranunculaceae). Botanichskii Zhurnal 100(3):270-277 (in Russian). [Буглова А.В. 2015. Фертильность, жизнеспособность и оптимальные сроки хранения пыльцы представителей рода Trollius (Ranunculaceae) // Ботанический журнал. Т. 100, №3. С. 270-277].

Buglova, L.V. \& A.A. Krasnikov 2015. Abnormalities in meiosis and pollen development in Trollius ledebourii (Ranunculaceae). Botanichskii Zhurnal 100(12):1269-1276 (in Russian). [Буглова А.В., Красников А.А. Нарушения в ходе микроспорогенеза и микрогаметогенеза у Trollius ledebourii (Ranunculaceae) / / Ботанический журнал. T. 100, № 12. C. 1269-1276].

Buglova, L.V. 2016. Microsporangium wall structure in Trollius ledebourii (Ranunculaceae). Rastitel'nyi mir Asiats koi Rossii 1(21):65-69 (in Russian) [^.В. Буглова. 2016. Строение стенки микроспорангия у Trollius ledebourii (Ranunculaceae) // Растительный мир азиатской России. № 1(21). С. 65-69].

Doroszewska, A. 1967. Chromosomes of some Trollius species. Acta Societatis Botanicorum Poloniae 36:567-577.

Doroszewska, A. 1974. The genus Trollius L. A taxonomical study (Monographiae botanica, vol. 41), Polskie Towarzystwo Botaniczne, Warszawa, $167 \mathrm{pp}$.

Feyberg, T.E. 1987. Verbenaceae family. Bignoniaceae family. In: Comparative embryology of flowering plants. DavidiaceaeAsteraceae (M.C. Jakovlev, ed.), pp. 219-225, 259-264. Nauka, Leningrad (in Russian). [Фейберг T.E. 1987. Семейство Verbenaceae. Семейство Bignoniaceae // Сравнительная эмбриология цветковых растений. Davidiaceae-Asteraceae / под ред. М.С. Яковлева. $\Lambda$. : Наука. С. 219-225, 259-264].

Friesen, N.V. 2003. Trollius L. In: Flora of Siberia. Vol. 6. (L.I. Malyschev \& G.A. Peschkova, eds.), pp. 98-103. Enfield, United States.

Jang, M.Y. \& K. Heo 2005. Reproductive morphology of Megaleranthis saniculifolia Ohwi (Ranunculaceae) and its systematic implications. Journal of Plant Biology 48(1):128-135.

Kadota, Y. 1987. Genus Trollius L. (Ranunculaceae) in Japan. Bulletin of the National Science Museum. Series B: Botany 13(3):107-121.

Kamelina, O.P., \& A.K. Dzevaltovsky 1987. Family Lamiaceae. In: Comparative embryology of flowering plants. Davidiaceae-Asteraceae (M.C. Jakovlev, ed.), pp. 225-236. Nauka, Leningrad (in Russian). [Камелина О.П., Азевалтовский А.К. 1987. Семейство Lamiaceae. Сравнительная эмбриология цветковых растений. Davidiaceae-Asteraceae. $\Lambda .:$ Наука. С. 225-236].

Kamelina, O.P. 2009. The systematic embryology of flowering plants. Dicots. Izdatelstvo Arktika, Barnaul, 501 pp. (in Russian). [Камелина О.П. 2009. Систематическая эмбриология цветковых растений. Авудольные. Барнаул: ИзА-во “Арктика". 501 с.].

Kerr, J.F. 1971. Shrinkage necrosis: a distinct mode of cellular death. Journal of Pathology 105(1):13-20.

Kim, M.Y. \& S.T. Lee 1987. Palynotaxonomic relationship of Megaleranthis saniculifolia Ohwi to the relative species (Ranunculaceae). Korean Journal of Plant Taxonomy 17(1):13-20.

Lee, S.T. 1990. On the taxonomic position of Trollius chosenensis Ohwi (Ranunculaceae). Korean Journal of Plant Taxonomy 20(1):1-8.

Li, L.Q. \& M. Tamura 2001. Trollius L. In: Flora of China. (Caryophyllaceae through Lardizabalaceae). Vol. 6. (Wu, Z.Y., P.H. Raven \& D.Y. Hong, eds.), pp. 137-142, Science Press \& Missouri Botanical Garden Press, St. Louis, Beijing.

Luferov, A.N. 1995. Globeflower - Trollius L. In: Vascular plants of the Soviet Far East, Vol. 7 (S.S. Charkevicz, ed.), pp. 15-21. Nauka, St.-Petersburg (in Rusian) [ $\Lambda$ фферов A.H. 1995. Купальница - Trollius L. / / Сосудистые растения советского Аальнего востока. СПб.: Наука. Т. 7. С. 15-21].

Malyshev, L.I. 2012. Ranunculaceae family. In: Conspectus florae Rossiae asiaticae: plantae vasculares (K.S. Baikov, ed.), pp. 20-35, Izdatel'stvo Sibirskogo otdelenia RAN, Novosibirsk (in Russian). [Малышев А.И. 2012. Семейство Ranunculaceae. Конспект флоры Азиатской России: сосудистые растения Новосибирск: ИзА-во СО РАН. C. 20-35].

Prosina, M.N. 1960. Botanical microtechnique. Nauka, Moscow, 199 pp. (in Russian). [Прозина М.Н. 1960. Ботаническая микротехника. М.: Наука. 199 с.].

Sha W., L.-H. Wang, X.-J. Yang, X.-L. Qi, G.-H. Ma \& D.-Y. Zhao 1995. Chromosome numbers of 20 species from northeast China. Journal of Wuban Botanical Research 32(2): 180-182.

Shamina, N.V., N.M. Kovaleva, O.A. Shatskaya \& E.D. Gavrilova 2004. Consolidation of cytoskeleton during plant spindle formation. I. Abnormalities of spindle integrity in meiosis. Tsitologiya 46(7):585-591 (in Russian) ШШамина Н.В., Ковалева Н.М., Шацкая О.А., Гавримова Е.А. 2004. Консолидация цитоскелета при формировании веретена Аеления в растительной клетке. I. Аномалии, затрагивающие целостность веретена в мейозе // Цитология. Т. 46, № 7. С. 587-591].

Shamina, N.V. \& N.V. Dorogova 2006. Dynamics of microtubular cytoskeleton in higher plant meiosis. VII. Mechanisms of the simultaneous cytokinesis. Tsitologiya 48: 127132 (in Rusian). Шамина Н.В. Аорогова Н.В. 2006. Аинамика микротрубочкового цитоскелета в мейозе у высших растений. VII. Процессы одновременного (симультанного) цитокинеза // Цитология. Т. 48, № 2. C. 127-132].

Shamina, N.V., O.A., Shatskaya, V.N. Solovjeva \& E.A. Blinova 2006. Polyarchal spindles in higher plant meiosis. Tsitologiya 48:114-119 (in Russian). Шамина Н.В., Шацкая О.А., Соловьева Н.В., Блинова Е.А. 2006. Многополюсные веретена в мейозе у высших растений // Цитология. Т. 48, № 2. С. 114-119].

Shamrov, I.I. 1986. Anther development in Gentiana lutea (Gentianaceae). Botanichskii Zhurnal 71(6): 733-739 (in Russian). Шамров И.И. 1986. Развитие пыльника у Gentiana lutea (Gentianaceae). Ботанический журнац. T. 71, № 6. C. 733-739].

Shamrov, I.I. 1987. Family Gentianaceae. In: Comparative embryology of flowering plants. Davidiaceae-Asteraceae. (M.C. Jakovlev, ed.), pp. 137-145. Nauka, Leningrad (in Russian). Шамров И.И. 1987. Семейство Gentianaceae. Сравнительная эмбриология цветковых растений. Davidiaсеае-Asteraceae. А.: Наука. С. 137-145].

Shamrov, I.I. 1988. Structure of septate anthers in some flowering plants. Annales scientifiques de l'Université de Reims et de l'ARERS 23:68-70.

Sokolovskaya, T.B. 1981. Family Ranunculaceae. In: Comparative embryology of flowering plants. Winteraceae-Juglandaceae. (M.C. Jakovlev, ed.), pp. 130-138. Nauka, Lvov (in Russian) [Соколовская Т.Б. 1981. Семейство Ranunculaceae. Сравнительная эмбриология цветковых растений. Winteraceae-Juglandaceae. Аьвов: Наука. С. 130-138].

Ter-Avanesyan, D.V. 1957. The pollination and genetic variation. Sovetskaya nauka, Moskov, 284 pp. (in Rusian) [Тер-Аванесян А.В. 1957. Опыление и наследственная изменчивость. М.: Советская наука. 284 с.].

Wang, S., Q. Tian \& F. An 2016. Growth inhibition and 
apoptotic effects of total flavonoids from Trollius chinensis on human breast cancer MCF-7 cells. Oncology Letters 12(3):1705-1710.

Wu, L.Z., H.F. Wu, X.D. Xu \& J.S. Yang 2011. Two new flavone C-glycosides from Trollius ledebourii. Chemical \& Pharmaceutical Bulletin (Tokyo) 59(11):1393-1398.

Zhou, X., J. Peng, G. Fan \& Y. Wu 2005. Isolation and purification of flavonoid glycosides from Trollius ledebourii using high-speed counter-current chromatography by step- wise increasing the flow-rate of the mobile phase. Journal of Chromatography A 1092(2):216-237.

Zou, J.H., J.S. Yang \& L. Zhou 2004. Acylated flavone Cglycosides from Trollius ledebourii. Journal of Natural Products 67(4):664-667.

Zou, J.H., J.S. Yang, Y.S. Dong, L. Zhou \& G. Lin 2005. Flavone C-glycosides from flowers of Trollius ledebourii. Phytochemistry 66(10):1121-1126. 